DOI: https://doi.org/10.4796o/2303-7431.24.2020.163

UDK: $81^{\prime} 282.8$

811.111 (o91)

Review article

Received on October 27, 2020

Accepted on March 16, 2021

ZORAN PERVAN

University of Mostar, Faculty of Humanities and Social Sciences

zoran.pervan@ff.sum.ba

\title{
SOCIAL ELEMENTS IN THE NORMAN FRENCH INFLUENCE ON ENGLISH
}

\section{Abstract}

The aim of the paper is to show the influence of Norman French on English after the Norman Conquest. The research is limited to vocabulary analysis as well as social changes that were introduced by William the Conqueror and made it possible for the influence to happen. The loss of the English nobility and William's replacement of it with the French, resulted with a discrepancy in the language of the lower and higher class. While the lower class continued to speak English, the higher class spoke French and speaking it soon became a matter of prestige, but also a matter of necessity for the lower class as they had no other means to communicate with the nobility. This soon led to the appearance of bilingualism which enabled the transfer and borrowing of French vocabulary into English.

Keywords: Norman French; Middle English; borrowings; language influence; history of the English language 


\section{Introduction}

When starting a typological comparison of languages, any linguistic system may be used as a starting point for comparison. We can compare languages based on their phonological, morphological, syntactic, semantic, pragmatic, etc. characteristics, and we look at language contact. As Velupillai (cf. 2012: 15) states, the aim of linguistic typology is to understand patterns in a language and why they occur. It is a natural phenomenon that languages that are closer to each other in space and time will have a certain influence on one another, depending how extensive the contact is and how the language policy is enacted. Today, a much stricter language policy is maintained, at least to a certain degree, in all official languages of the world. However, during past times, such policies did not exist and depending on certain historical and social contexts, languages evolved quite freely depending on external influences.

A prolonged contact existed between the English and the French language after the Norman conquest in 1066 and lasted all the way up to the $14^{\text {th }}$ century. This period is referred to as the Middle English period and it is a period of great change in the history of the English language. This was due to the fact that the Normans brought with them many social changes which affected all aspects of life in Britain. Along with the social change, a language change followed as the people in England conformed to the new ruling class. In such circumstances, many French words entered the language and this influence was restricted to vocabulary.

In this paper, a diachronic comparison of English and French will be shown, and the historical and social context will be explained in order to understand why French had such abundant influence on English. The first chapter deals with language typology, and a basic concept of exploring and comparing languages will be shown. The second chapter outlines the genealogy of the English and French language in order to see their similarities and why borrowing from one language into the other is easily done as they belong to the same language family. The third chapter addresses the Norman Conquest and discusses the social 
context that was present after the Conquest. French influence on the vocabulary is discussed here. The fourth and final chapter deals with the re-emergence of English and the way code-switching influenced further adoption of French vocabulary.

\section{Language Typology}

Languages are different. This is a fact that most of us (if not everybody) have experienced at least once in a lifetime when we have overheard some strangers talking. While the noises that they made might have occurred to us as random noises, we are aware of the fact that they are communicating. Take a look at the following example:

She makes bread every day. English

Ona pravi kruh svaki dan. Croatian

Elle fait du pain tous les jours. French

Sie macht jeden Tag Brot. German

When we take a closer look at the examples we can see that despite the differences between the sentences in various languages, there are a lot of similarities between them. For instance, each of them begins with a subject $(\mathrm{S})+$ verb $(\mathrm{V})$ combination (she makes, ona pravi, elle fait, sie macht) and even some of the words are similar (makes-macht, day-dan, brot-bread). So why are languages at the same time so different that when we hear them the first time they sound completely strange to us, but at closer inspection they start showing similarities? And what is the reason for these differences and similarities? To answer these questions, we have to take a look at language distribution and try to explain it. What occurs where, and why does it occur where it does? (cf. Moravcsik, 2013: 3)

For the examples listed above there is a simple explanation to their similarities; they all belong to the same Indo-European language family, which means that they descended from the same language, which is referred to as Proto-Indo-European. Although this explanation is the simplest, it has to be pointed out that Proto-Indo-European is a reconstrued, 
physically not attested proto language. Of course, not every similarity is the result of a common ancestor. Language contact is another reason why sometimes languages which are part of different language families have some similarities. For example, the word for sugar came from Sanskrit 凶arkarā. Indian merchants began exporting sugar cane across the world in the $8^{\text {th }}$ century and the word with it. That is why today we have in English sugar, Croatian šećer, German Zucker, French sucre, Hungarian cukor, Hebrew sukkar, Swahilli sukari, and so on. (cf. Moravcsik, 2013: 4) So, it can be seen that languages influence each other under certain historical circumstances. Sometimes the influence is limited to few words as there is no prolonged language contact between languages, but sometimes that contact lasts for a longer period of time and one language can drastically influence the way another language will develop.

When we talk about similarities and differences between languages like this, we are still aware that they are separate languages, hence we divide them into groups, we classify them. Language classification can be approached in two different ways: genealogical and typological. (cf. Ivić et al., 2020) Genealogical classification groups languages into language families based on their relatedness through time. On the other hand, typological classification groups languages based on their structural characteristics, i.e. the structural differences and similarities between languages. (cf. Velupillai, 2012: 20)

\section{Genealogy of English and French}

English and French both belong to the Indo-European family of languages, which means that they share the same ancestor language which is referred to as Proto-Indo-European. This can be inferred based on cognate words from both languages. Indo-European is thought to have been firstly split into Eastern and Western branches based on the difference of the sound k- and s-. For example, the word satam in Sanskrit or suto in Old Slavic changed the from the original Indo-European $\mathrm{km}$ tóm, while in the Western languages it remained, as in Celtic cant or 
Latin centum, which then changed to an h- in the Germanic languages; hundred. The Eastern branch split into two, the Balto-Slavic and the Indo-Iranian, while the Western branch split into Hellenic, Italic, Celtic and Germanic. (cf. Williams, 1975: 47) Other scholars include several other branches, e.g. Singh (cf. 2005: 51) includes Tocharian, Anatolian, Armenian and Albanian with the latter two forming stand-alone branches, so called isolates. For our purposes the branches of Germanic and Italic are the most important so only those will be described in more detail.

The Germanic branch is usually divided into three sub-branches, East, North and West Germanic. The East Germanic branch includes only the Gothic language, which is now a dead language. The North Germanic includes Icelandic, Norwegian, Danish and Swedish. The West Germanic branches out into two, High German and Low German. High German branches out into German and Yiddish and Low German branches out into Frisian, Dutch, Flemish, Afrikaans and English. (cf. Singh, 2005: 51) It has to be stated that different authors give different classifications, e.g. Williams (cf. 1975: 48) does not divide the West Germanic branch into High and Low Germanic, but classifies them as separate languages alongside Dutch, Flemish, Afrikaans, Yiddish, Frisian and English.

Anglo-Saxon invading tribes to England, which originally came from the area of today's northern Germany and Denmark, never called their language anything but "Englisc", so we have the mention of the English language dating back to the $7^{\text {th }}$ century. (cf. Baugh - Cable, 2002: 45) It is not known whether the invaders had spoken a single tongue or various dialects, although it is probable that various dialect were used by different tribes. The British island was ruled by the Romans before the Anglo-Saxon invasion, but this was not the first contact that the Germanic tribes had with Latin language and culture. This can be seen from the variety of words adopted into the language before the invasion, most of which have a connection to military or food. Among others, words such as camp, toll, mile, monger, pound, butter, cheese, wine, pepper, kitchen were adopted. (cf. Williams, 1975: 50) It can be concluded that the tribes had organized trade with the Romans, but also that they were familiar 
with their military forcing us to conclude that they probably served in the Roman army as well.

The period from the Anglo-Saxon invasion until 1066 is called the Old English period. The language of this period is highly inflectional and was synthetic like the rest of the Germanic languages. It had four cases (sometimes even the fifth occurs), different articles representing different genders, dual number which makes it more similar to Modern German than Modern English. Since this period was relatively calm for a longer period of time, English had no major influences besides Latin and Old Norse in the $9^{\text {th }}$ and $10^{\text {th }}$ century, when the Vikings started to raid the island. (cf. Baugh - Cable, 2002: 46)

The Middle English period began in 1066 with the Norman Conquest and this changed the English language radically. This event had an everlasting impact like no other in the history of the English language. The Normans were Vikings or Norsemen who settled in the North of France and founded their own duchy there. They quickly assimilated with the local Frankish people, adopted their language and culture and eventually converted to Christianity. (cf. "Norman". Encyclopedia Britannica, 2015) But while they adopted the language of the locals, they retained a lot of Scandinavian words which made their language a distinct dialect different than the French spoken in Paris which became the standard French dialect, but the two dialects were mutually intelligible. When William the Conqueror took the throne of England, England and France remained in a close contact over the next 300 years, so when English became the official written language of England again, it was deeply changed and influenced by French and these changes proved to be permanent.

The Middle English period lasted until the year 1500 and since then, we are in the Modern English period, which is usually divided into Early Modern English period, lasting until the year 180o, and Late Modern English period, which started in 1800 and has lasted until today. The most important thing that occurred in this period was the invention of the printing press. This allowed for books and pamphlets to be printed in larger quantities and reach a wider number of people who would 
never have the chance to possess something like that earlier. What is more important, if somebody printed a hundred, or a thousand copies of a book, each copy was exactly the same and this proved pivotal in the standardization of speech. And since the major printing houses were in London, soon the dialect of the capital had more influence than other dialects that were present on the island. In this way the East Midland dialect became the basis for standard English. (cf. Baugh - Cable, 2002: 187)

Only Latin belongs to the Italic branch of Indo-European out of which stem out French, Spanish, Italian, Portuguese, Catalan, Provencal and Romanian. (cf. Singh, 2005: 51) French developed from Latin as the area which is now known as France was once occupied by the Roman Empire. But the language spoken in that area was not Classical Latin, the one that was used by the church or by scholars across Europe, but Vulgar Latin which was used by soldiers and commoners in everyday life and trade. One particularity of Vulgar Latin was that it had developed differently in different areas that were once occupied by the Roman Empire due to the contact with different people. The Romans who inhabited the lands west of the Rhine (Gaul) came in contact with Gaulish, a Celtic language and after the collapse of the Roman Empire various Germanic tribes raided the area, among which the Visigoths and the Franks - who gave the county its name - stand out the most. All of the circumstances directed the way in which Vulgar Latin of this area would develop. While few Celtic words remained in the language, the Germanic influence was great and the language was enriched by Germanic vocabulary and a clear influence can be seen in phonetics. (cf. Driver Howarth et al., 2019)

One particularity of the French language are the various dialects it developed. The early texts, which come from the $9^{\text {th }}$ century written in the vernacular show a distinction between the north and south of Gaul. The major distinction was between langue d'oil which was spoken in the north and langue d'oc which was spoken in the south. The different names came from the words oil and oc which were variations of the word yes. Langue d'oil did not have a uniform development across 
all areas of the north and various dialects developed: Francien, Picard, Champenois and Norman. Francien went on to become the basis from which Modern French was to develop, because it was the language of Paris. (cf. Driver Howarth et al., 2019) The last of the mentioned dialects, Norman, was the one from which Anglo-Norman stemmed and it was the dialect which had a great impact on the development of the English language.

When Old French and Latin are compared, a lot of similarities can be seen: word order, case system, number of vowels and noun and adjective declinations among others. But as French language evolved to its Middle French period, a number of changes can be seen in the mid- $11^{\text {th }}$ and $12^{\text {th }}$ century. The case system disappeared, final consonants were dropped which meant that declinations were lost, diphthongs and vowels were reduced, the use of determiners was increased and the word order became more fixed which marked a change towards a more analytic language. (cf. Fagyal - Kibbee - Jenkins, 2006: 248) Although these changes refer to the Francien dialect, they can be tied with other dialects as well, because the Norman dukes were subjected to the court in Paris and had to maintain contact with them. So, it would be reasonable to consider that the changes that happened influenced Norman French as well.

Another fact that supports this claim is that Anglo-Norman, the language of the Normans that developed in England in the centuries following the Conquest, was often ridiculed as a poor version of "proper" French which was spoken on the Continent. This was not the case in the $10^{\text {th }}$ or $11^{\text {th }}$ century. When the king of France crushed the duchy of Normandy in 1204 and took control of it, the ties between England and Continent began to weaken. What this meant for language was that the central Francien dialect which was spoken in Paris began to take control over every part of France, including Normandy. The Anglo-Norman which was spoken in England became almost obsolete to such an extent that Parisian French was beginning to be taught in England. (cf. Knowles, 1997: 47)

The Old French period lasted until the end of the $13^{\text {th }}$ century. The Middle French period lasted from the $14^{\text {th }}$ until the $17^{\text {th }}$ century and it 
marked the stabilisation of the Francien dialect as a standardised variant. In the $16^{\text {th }}$ century Robert Estienne published the first dictionary which included a grammar. It is also notable that Estienne was a famous printer and that French began its standardisation throughout the country due to the printing press, the same as English did. The most important act for the language from this period is the Ordonnance de Villers-Cotterêts from 1539, which stated that all legal acts must be conducted in "langage maternel françois" or "the maternal French language", which was unambiguously interpreted as being the King's French. (cf. Faygal - Kibbee - Jenkins, 2006: 248) This is another important point in time, as the Francien dialect was now used to disseminate knowledge and in this was unified the language in the whole country.

The Modern French period started in the $17^{\text {th }}$ century when it gained such popularity that it was spoken all over the European courts and in turn it replaced Latin as a universal language. It became lingua franca. The Académie Française was formed in 1635 and it had the goal of making the language a medium for Arts and Sciences. (cf. Faygal - Kibbee - Jenkins, 2006: 270) The Académie has done activities to standardise the language - something that English never had - and it acts until this day on matter which pertain to the French language.

\section{The Norman Conquest and the New Social Context}

According to van Gelderen (cf. 2006: 99) the influence of French on English happened in two phases, the first one being from 1066 until 1250 and the second one being from 1250 to 1500 . In the first phase, only around 1000 words have entered the English language, while in the second phase estimates say that around 10000 words were borrowed from French. The second phase is clearly more important and had more influence on the development of the English language. This is due to the fact that the Norman nobility had to turn their attention to England after 1204, because they were cut off from their lands and possessions in Normandy. Knowles (cf. 1997: 47) claims that bilingualism was widespread in England after the time of the conquest. This seems to be 
a reasonable assumption as the nobles could not have ruled over their serfs if they had not known their language. But, after the loss of Normandy it is only reasonable to think that the Normans began to think of themselves as Englishmen, (cf. Baugh - Cable, 2002: 117) and begin using the English language all the time with little to no regard of using French as their primary language anymore. What is important to highlight in such circumstances is the fact that when the Norman nobility began using English as their primary language, it was not their mother tongue, and they inserted a lot of French elements in their speech. This explains the fact that in the second period, i.e. after 1250, more than 10000 French borrowings are registered in the English language.

During this time period another language played an important part in the official language policy and thus shaped the way in which English developed - Latin. Latin was the language of record, meaning that all official document had to be written in it. Although during the $11^{\text {th }}$ and $12^{\text {th }}$ centuries there are bilingual records written in Latin and English, the latter faded away and with the Norman aristocracy ruling, French slowly became the alternative to Latin eventually even becoming the dominant language in courts. A person speaking in English in the court would have their speech transcribed to French, so there is no way of knowing which language was actually used unless it is specifically stated. (cf. Knowles, 1997: 49) From 1362 English was used in courts, although French remained the formal language of the courts all up to the $18^{\text {th }}$ century.

Before the Norman Conquest the language of the law in England was English and Latin. After the Conquest things changed and English was no longer in use as new ruling class did not know how to speak English. The influence of the Norman French on English was a typical conquering superstrate. In such a situation, borrowing happened by forced contact. The ruling class set up new rules for state and communal life using their language in the process, and the lower classes had to learn this new nomenclature if they wanted to be a part of and actively participate in the society. (cf. Vennemann, 2011: 240) 
After the Norman conquest the English society changed completely. The French did not bring solely their language and culture with them, but also the legal and political systems. The society became highly hierarchal, and the feudal system was introduced which meant that the king owned all of the land in the country. The Domesday Book, which was written by the order of William the Conqueror in 1082 in order to determine how much taxes are owed to the king, clearly shows that almost no English landlords existed during this time period. This meant that the higher class of society was rid of English and Norman French became the language of the ruling class in speaking and in writing. In fact, those are the two ways that French influenced English during this period. (cf. Horobin - Smith, 2002: 27) However, the influence through writing did not come until the late $12^{\text {th }}$ century or even up to mid- $13^{\text {th }}$ century when English began to reappear in writing. The Peterborough Chronicle is the last remnant of Old English and it had its last entry written in 1154. Without an educated upper class that would introduce and abide to the rules of a language, English soon developed various regional dialects that would become a central characteristic of the Middle English period. (cf. Horobin - Smith, 2002: 30)

\subsection{French Influence on the Vocabulary}

When French became the language of the enemy and the English ruling class began to accept English as their own tongue, English began to reappear in legal documents. This is where French had an influence on English in writing, as the clerks who used to write legal documents in French now began doing so in English and they would borrow features of written French into English. (cf. Knowles, 1997: 51) Before French had an impact in this way, the influence was through speech. As the language of the court was French and Latin, a peasant who would come to the court would have to know the basic terminology. This was a way for French to enter the language of the masses because soon even the peasants were saying justice and equity, rather than gerihte, judgement rather than dom, crime instead of synn or gylt. In the same way words 
such as bar, assize, plea, suit, plaintiff, defendant, judge, advocate, attorney, bill, petition, complaint, summons, indictment, jury, juror, panel, felon, evidence, proof, bail, ransom, judgment, verdict, sentence, decree, award, fine, forfeit, punishment, prison, etc. are a part of legal terms used today. Even the names of crimes come from French: felony, trespass, assault, arson, fraud, libel, slander, perjury, adultery, etc. Lawsuits involving property brought about words such as property, estate, tenant, dower, legacy, patrimony, heritage, heir, executor, etc. (cf. Baugh - Cable, 2002: 158)

Other aspects of the society in which Norman French had an influence were in fashion and cuisine. Fashion should not be surprising as during these times it was exclusively associated with the upper class. The words fashion and dress are themselves French, as are apparel, habit, gown, robe, garment, attire, cape, cloak, coat, frock, collar, veil, train, chemise, petticoat. So too are lace, embroidery, pleat, gusset, buckle, button, tassel, plume, and the names of such articles as kerchief, mitten, garter, galoshes, and boots. (cf. Baugh - Cable, 2002: 159) The English dinner table would be quite different if there had been no French influence. Words dinner and supper are of French origin, as are feast, appetite and taste. Names of fish, mackerel, perch, bream, salmon, sardine, oyster, and names of meats, venison, beef, veal, mutton, pork, bacon, sausage are of French origin as well. Spice, clove, thyme, herb, mustard, vinegar, cinnamon, nutmeg, toast, biscuit, cream, olives, salad, lettuce, raisin, date, fig, grape, orange, lemon are all of French origin. (cf. Baugh - Cable, 2002: 159) It is hard to imagine how we would enjoy our food today without such a rich vocabulary. Other areas of life where French had an influence were government, art and religion. Van Gelderen (cf. 2006: 99) lists a number of words from these areas which have been borrowed after 1066. These include government, royal, state, authority, prince, duke, art, sculpture, music, painting, colour, figure, image, temptation, damnation, salvation, confess, convert, baptism, etc. This is, of course, not a complete list, as such a list would be too extensive for the purposes of this paper. 


\section{Re-emergence of English}

The first document to be published in English after the Conquest were the Provisions of Oxford in 1258, which resolved a feud between Henry III and the English barons. The document was written in Latin, French and English and the usage of English language showed that the upper class were no longer solely French, but that they were bilingual at least. Around this time aristocratic literature began to appear in English. (cf. Knowles, 1997: 50) In 1337 the Hundred Years' War started and it had a huge impact not only on English language, but culture as well. "One of the effects was to force Englishmen and Frenchmen to see themselves as belonging to different peoples." (Knowles, 1997: 51) During the course of the war Englishmen started to take over various positions in the state and the church which were previously assigned to Frenchmen. In 1352 Ranulph Higden wrote Polychronicon in which he is implying that French at that time is no longer the first language of the upper class in Britain.

When English began to assume its prior position and slowly rose up to be the primary language, there was a transition period in which bilingual people would use both language and switch from one to another during speech or even during a letter. Knowles (cf. 1997: 55 - 56) gives us an example of a letter of Richard Kyngston to Henry IV which was written in 1403. The letter starts in French,

Please a vostre tresgraciouse Seignourie entendre que a-jourduy apres no one ... q'ils furent venuz deinz nostre countie pluis de cccc des les rebelz de Owyne, Glyn, Talgard, et pluseours autres rebelz des voz marches de Galys, et ount prisez et robbez deinz vostre countie de Hereford pluseours gentz, et bestaille a graunte nombre.

but in the middle of the letter it switches to English.

Warfore, for goddesake, thinketh on sour beste frende, god, and thanke hym as he hath deserued to sowe!

He even switches between languages in the middle of sentences. 
Jeo prie a la benoit trinite que vous ottroie bone vie ove tresentier sauntee a treslohge durre, and sende sowe sone to ows in help and prosperitee.

In legal texts code switching of this kind survived for a long time, all the way up to the $17^{\text {th }}$ century. Chambers (1932: 82) says that "the English began to conduct their legal business, first of all in the French language, and then in no language at all." What this meant was that the language in the legal system was a mix between the two languages and code switching was a common occurrence. In such an environment French vocabulary passed into English with ease, and it is no wonder that today there are so many French words in English today. Some estimates even say that 30\% of all the words in English today are of French origin.

One thing that is important to highlight is that the influence of French was restricted to vocabulary. Baugh and Cable (cf. 2002: 155) claim that the syntactic changes that happened during this period, the SVO word order, and the loss of inflections, did not happen under a direct influence of French, but were the result of external influences in the sense that the usage of French during this period enabled such changes to happen. In this sense, the influence of French on English syntax and morphology is only indirect.

\section{Conclusion}

Languages can be compared based on the social context or special social circumstances which would provoke usage of different languages. Such a context can be found in the $12^{\text {th }}$ and $13^{\text {th }}$ century Britain, where the majority of the people used English in everyday speech, but when social convention demanded it, French was used. This is true of art, culinary, law and basically any form of communication that was deemed educated or had any connection to the higher class. Speakers had to preserve their image in such situations and that is why they used French instead of English, as English was considered the language of the peasantry. 
Based on the examples that were shown, it can be seen that the English vocabulary owes a great deal to the French language. However, this is not all that strange, as languages are under the influence of other contact languages and they borrow words for concepts which are new to them or have no equivalent in their native tongue. Although Old English borrowed from Latin, Celtic and Old Norse, the major influx of new vocabulary units came during the Middle English period. The social context enabled such extensive borrowing, as French became an official language of the higher class and soon after the new social hierarchy was established, many people became bilingual.

With no power to give clear rules on how the language should be used, English changed a lot during the Middle English period. Further research could be done on morphology and syntax of the English language during this period and to see precisely whether the influence of French was really indirect or if it had a more extensive role in the shift of English from a synthetic language to an analytic one.

\section{Bibliography}

- "Norman", Encyclopedia Britannica, (4 IX 2015), <https://www. britannica.com/topic/Norman-people>, (29 X 2020).

- Baugh, Albert Croll - Cable, Thomas (2002) A History of the English Language, $5^{\text {th }}$ ed., Routledge, London.

- Chambers, Raymond Wilson (1932) “The continuity of English prose from Alfred to More and his school”, Нiтcнсоск, Elsie Vaughan (ed.), Harpsfield's life of More, Early English Text Society, London, pp. $65-154$.

- Driver Howarth, William et al. "French Literature", Encyclopcedia Britannica, (15 X 2019), https://www.britannica.com/art/ French-literature, (10 VIII 2020)

- Fagyal, Zsuzsanna - Kibbee, Douglas - Jenkins, Frederic (2006) French: A Linguistic Introduction, Cambridge University Press, Cambridge. 
- Horobin, Simon - Smith, Jeremy (2006) An Introduction to Middle English, Edinburgh University Press, Edinburgh.

- Ivić, PAVle - Lyons, John et al. "Language Clasification", Encyclopaedia Britannica, (11 II 2020), <https://www.britannica.com/ science/linguistics/Language-classification>, (29 X 2020).

- Knowles, Gregory (1997) A Cultural History of the English Language, Arnold, London.

- Moravcsik, Edith A. (2013) Introducing Language Typology, Cambridge University Press, Cambridge.

- Singh, Ishtla (2005) The History of English: A Student's Guide, Hodder Education, London.

- Van Gelderen, Elly (2006) A History of the English Language, John Benjamins Publishing Company, Amsterdam - Philadelphia.

- Velupillai, Viveka (2012) An Introduction to Linguistic Typology, John Benjamins Punlishing Company, Amsterdam - Philadelphia.

- Vennemann, Theo (2011) "English as a Contact Language: Typology and Comparison", Anglia, vol. CXXIX, no. 3 - 4, p. 217 - 257.

- Williams, Joseph M. (1975) Origins of the English Language: A Social and Linguistic History, The Free Press, New York. 
Pregledni članak

Primljen 27. X. 2020.

Prihvaćen 16. III. 2021.

Zoran Pervan

Sveučilište u Mostaru, Filozofski fakultet

\section{DRUŠTVENI ELEMENTI U UTJECAJU NORMANSKOGA FRANCUSKOG NA ENGLESKI}

\section{Sažetak}

Cilj je rada prikazati utjecaj normanskoga francuskog jezika na engleski jezik nakon normanskoga osvajanja Engleske. Istraživanje je ograničeno na analizu vokabulara i na društvene promjene koje je uveo Vilim Osvajač, a koje su omogućile da se izvrši jezični utjecaj. Gubitak engleskoga plemstva i činjenica da ga je Vilim zamijenio francuskim iznjedrili su raskorak u jeziku među nižim i višim slojevima društva. Dok su niži slojevi nastavili govoriti engleski, viši slojevi govorili su francuski. Na taj je način uporaba francuskoga uskoro postala stvar prestiža, ali i potrebe za niže slojeve društva koji su dugi niz godina mogli komunicirati s plemstvom samo na francuskome. Posljedica je toga bila da su mnogi pojedinci uskoro bili dvojezični, što je omogućilo posuđivanje francuskoga vokabulara u engleski jezik.

Ključne riječi: normanski francuski; srednji engleski; posuđenice; jezični utjecaj; povijest engleskog jezika 